\title{
Implementation of PP NOMOR 23 TAHUN 2018 on the Tax Cmplianc of Micro, Small and Medium Enterprises (UMKM) in Semarang City
}

\section{Atta Putra Harjanto, Subowo, Kiswanto, Hayat Widodo, and Nani Fitriani}

Department Accounting, Economics Faculty, Semarang State University - Indonesia

\section{Abstract}

This research aims to examine the influence of the application of Government regulation (PP) number23 of 2018 on tax compliance for Micro, Small and Medium Enterprises (UMKM) in Semarang city. Implementation of PP No.23 of 2018 is proxied by the variables of taxation knowledge and taxation sanctions. This is a quantitative research using primary data. The data are collected using questionnaire and analyzed using multiple regression. The data are processed using SPSS to analyze the data, and the research samples are selected using the questionnaire. The population of

Corresponding Author: Atta Putra Harjanto attaputraharjanto@gmail.com

Received: 7 February 2020 Accepted: 9 March 2020 Published: 23 March 2020

Publishing services provided by Knowledge E

(c) Atta Putra Harjanto et al. This article is distributed under the terms of the

Attribution License, which permits unrestricted use and redistribution provided that the original author and source are credited.

Selection and Peer-review under the responsibility of the ICE-BEES 2019 Conference Committee.

\section{G OPEN ACCESS}

this research is the Micro, Small, and Medium Enterprises in Semarang, especially the Courses and Training institutions. There are 208 valid and reliable samples for further analysis. The results show that the application of PP No.23 of 2018 in Semarang affects the tax compliance of UMKM. This shows that the understanding of new regulations and sanctions positively influences the tax compliance among the UMKM. Due to the chosen research approach, the results are specific and may be less generalizable. Therefore, further researchers are encouraged to test the hypotheses submitted to other objects. This research includes implications for the tax regulators in implementing new regulations that are able to significantly influence the UMKM in the future.

Keywords: Tax Knowledge, Tax Sanctions, Tax Compliance, PP Nomor 23/2018, UMKM

\section{Introduction}

To be able to grasp an independent economics, the government of a country in general reduces its funding from abroad, and greatly optimizes financing from the tax sector. The tax sector is the largest revenue contributor sector for the central and regional governments, and is the easiest sector for the tax collection. This can be done because the tax levy is supported by the applicable Taxation Laws.

The definition of tax according to the National Law No. 16 of 2009 concerning General Taxation Provisions and Procedures (KUP) article 1 paragraph 1 is a mandatory and 
forcing contribution to the state owed by individuals or entities based on the law by not getting a direct reward and used for public purposes as much as possible for the prosperity of the people. Tax has an important role in a country, especially related to sustainable national development programs in various sectors to improve the people's welfare. Based on the realization of the State Expenditure Budget (APBN), it shows that tax is the largest source of state revenue. The tax contributes the revenue of $\operatorname{Rp} 1,521.4$ trillion from total state revenue in 2018 of $\mathrm{Rp} 1,942.3$ trillion

One factor that hinders the effectiveness in the tax collection is the taxpayers' compliance. According to [1], the low compliance of the taxpayers is caused by low quality services presented by the tax officers, perceptions of taxpayers about the taxes and their lack of tax knowledge. Many ilegal taxation cases in Indonesia in recent years have made people and the taxpayers worry and fret to pay the tax. Such conditions will be surely able to affect the taxpayer obligations. This is because they do not want the tax that has been deposited to the state is misused by the tax authorities. So, the impact is the level of tax compliance has decreased.

Tax knowledge is all tax-related information that can be used by the taxpayers as a basis for acting, making decisions, and taking a strategy in connection with the implementation of their rights and obligations in the taxation field [2]. Less taxpayers' knowledge about the tax regulations makes them cannot fulfill their obligations as the taxpayers and their understanding of the benefits of tax revenue is not also good [3]. Tax regulations that have been socialized by the Directorate General of Taxes are still not comprehensive to every taxpayer, resulting in the lack of taxpayers' knowledge related to the taxation information

Lack of knowledge of the taxpayers will lead to their low level of awareness to meet the obligation to pay taxes and submit Annual Tax Returns. The low awareness of the taxpayers will also result in the low level of taxation compliance. If the level of compliance is low, it will result in state income from tax that will be reduced and miss from the tax revenue target. However, if the taxpayers;' compliance level is high, it will cause the state revenue to increase and may exceed the target.

The knowledge and awareness of the taxpayers will also have an impact on the sanctions that they will receive. The implementation of tax sanctions will be far more detrimental to the taxpayers if they do not fulfill their tax obligations. The sanctions can be in the form of administrative, fines, and criminal sanctions. Therefore, the implementation of the tax sanctions that are applied as a result of non-compliance of the taxpayers in tax obligations will lead to increased taxpayer compliance. 
Research on the factors that influence the tax compliance has been done by previous researchers which show inconsistent results. The research related to the tax knowledge on the tax compliance conducted by [3] found that the taxation knowledge has a positive effect on the tax compliance. Furthermore, this research is supported by the research conducted by [4], showing that the tax knowledge has a positive effect on the tax compliance. [5] stated that the tax knowledge has a positive effect on the tax compliance. However, there are different results shown by [6] who explained that the knowledge of tax regulations does not affect the tax compliance.

A research was conducted by [7] on rhe awareness of the taxpayers, tax sanctions, tax authorities on individual taxpayer compliance. The results of this research showed that the sanctions for the taxpayers have a significant effect on their tax compliance. A clear legal basis for the taxation sanctions is regulated in the General Tax Provisions Act. The research is supported by [8] and [9] saying that the tax sanctions has a positive influence on the tax compliance. However, the results are different from the research of [10] finding that the tax sanctions do not affect the tax compliance

The purpose of this research is to analyze the influence of the implementation of PP 23 of 2018 on the tax compliance at UMKM in Semarang city. The dependent variable is the tax compliance, while the independent ones are knowledge of taxation and taxation sanctions which are allegedly able to increase the level of tax compliance.

\section{Theoretical Framework}

The factors examined in this research are related to taxpayer compliance behavior in carrying out their tax obligations. The taxpayers' compliance depends on their behavior or actions. Theory of planned behavior is used to explain a person's behavior towards his tax compliance behavior. Theory of planned behavior explains that a behavior arises from an individual caused by the intention to behave. If a taxpayer has good intentions to calculate, deposit, and report his payable tax, then the level of his tax compliance will increase. Furthermore, the taxpayers will not get sanctions inbased on applicable regulations. However, if they have an intention not to comply with the rules, then they will get the sanctions for in accordance with applicable taxation laws.

\section{Development of Hypotheses}

The tax knowledge has a function as a guideline in carrying out the tax obligations, such as calculating, depositing, and reporting the amount of tax owed. According to 
[2] in his research on the tax compliance, the tax knowledge is explained as the tax information that can be used by the taxpayers as a basis for acting, making decisions, and determining strategies in relation to the rights and obligations as the taxpayers. [11] concluded that in addition to the tax knowledge, understanding and awareness of the taxpayers is very important to influence the level of tax compliance

Tax knowledge is a basic guideline for the taxpayers in fulfilling the tax obligations. Tax knowledge is the most influential factor in determining the taxpayers' compliance behavior that applies a self assessment system [12]. The higher the knowledge and understanding of the taxpayers, they can determine their behavior better and in accordance with tax regulations. If they do not have adequate knowledge on the taxation regulations and processes, they cannot determine their behavior correctly. A taxpayer who knows and understands the applicable regulations and is aware of the implementation of policies that require independence will have compliance in carrying out his obligations. The research conducted by $[3,4]$ and $[5]$ stated that the tax knowledge has a positive influence on the tax compliance.

\section{$\mathbf{H}_{1}$ : Tax knowledge significantly influences the tax compliance}

The government has prepared the rules stipulated in the applicable Taxation Law so that the implementation of tax collection can be orderly done and in accordance with the expected target. If the tax obligation is not implemented well, then there are legal consequenc that may occur, because the tax contains an element of coercion. The legal consequence in question is the imposition of tax sanctions [13]. In a study conducted by [2], the tax sanctions are statutory regulations that must be obeyed so that the taxpayers do not violate the tax norms

Heavy sanctions imposed on the taxpayers who do not meet their tax obligations are expected to affect their compliance. A research conducted by [7] showed that the tax sanctions have a significant influence on the tax compliance. A clear legal basis for the taxation sanctions is regulated in the General Tax Provisions Act. The research is supported by [8] and [9] saying that the tax sanctions has a positive effect on the tax compliance.

\section{$\mathrm{H}_{2}$ : Tax sanctions significantly influences the tax compliance}

\section{Research Methods}

The data used in this research were primary one, obtained directly and collected by the researchers from some respondents. The respondents of this research were the taxpayers of UMKM in Semarang which operated in the Course and Training Institution 
(LKP) sector. The population was the whole object of the research. This research used UMKM as the sample, located in Semarang city which were engaged in the Courses and Training Institutions.

The dependent variable in this research was the tax compliance. The tax compliance was defined as a behavior of the taxpayers that referred to the level of compliance in terms of fulfilling their tax obligations both in calculating, depositing and or reporting the tax payable. The independent variable was the taxation knowledge which meant an understanding that referred to an individual's way of assessing and understanding the meaning of something. Severe tax sanctions were given to the taxpayers who commited the tax violations which were expected to motivate them to be able to comply with applicable tax regulations.

The data were collected using census method, where the population is equal to the number of samples, by distributing a list of questions (questionnaire) that would be filled or answered by the respondents. Measurement of dependent and independent variables was done using question-shaped instruments and five-point Likert scale. This research used descriptive statistical analysis and multiple linear regression using IBM SPSS version 21. Before conducting regression analysis, the research data were tested first using validity and reliability tests, and then proceeded for the classical assumptions tests which include normality, multicollinearity, and heteroscedasticity tests. The equation model that was applied using the regression test was:

$$
\mathrm{KEP}=\alpha_{0}+{ }_{\beta 1} \mathrm{PGTP}+{ }_{\beta 2} \mathrm{SNP}+\mathrm{e} .
$$

\section{Results and Discussions}

Descriptive statistics provide a description of the data theoretically and empirically, which includes mean, variants, maximums and minimums. The descriptive statistical test results can be observed in Table 1:

The validity test results show that all indicators used to measure the research variables are valid. It is found that the indicators used in this study have correlation coefficient value higher than $r_{\text {table }}$ for $n=208$, which is 0.136 . As for testing the reliability of all variables, the Cronbach's Alpha value is higher than 0.70 . Thus, it can be concluded that all the concepts of the measurement of the variables are reliable. Such conditions show that all variables can be used in subsequent analysis.

Before the hypothesis testing is conducted, the claasical assumption test is firstly done on the regression model. The test results are shown in Table 2: 
TABLE 1: Results of Descriptive Statistics

\begin{tabular}{|l|c|}
\hline Variable & Size \\
\hline Tax knowledge & Minimum \\
\hline & Maximum \\
\hline & Mean \\
\hline Tax Sanctions & Minimum \\
\hline & Maximum \\
\hline Kepatuhan Pajak & Mean \\
\hline & Minimum \\
\hline & Maximum \\
\hline
\end{tabular}

\begin{tabular}{|c|}
\hline Theoretically \\
\hline 5 \\
\hline 25 \\
\hline 15 \\
\hline 5 \\
\hline 25 \\
\hline 15 \\
\hline 7 \\
\hline 35 \\
\hline 21
\end{tabular}

\begin{tabular}{|c|}
\hline Empirically \\
\hline 16 \\
\hline 25 \\
\hline 21.15 \\
\hline 15 \\
\hline 25 \\
\hline 20 \\
\hline 24 \\
\hline 35 \\
\hline 29.53 \\
\hline
\end{tabular}

Source: Processed primary data, 2019

TABLE 2: Results of Classical Assumption Test

\begin{tabular}{l|c|c} 
& Normality Test & \\
\hline $\begin{array}{l}\text { One-sample Kolmogorov } \\
\text { Smirnov }\end{array}$ & Statistics Test & Asymp.Sig.(2-tailed) \\
& 1,206 & 0,109 \\
\hline VIF and Tolerance test & Multicollinearity Test & VIF \\
\hline PGTP & Tolerance & 2,475 \\
\hline SNP & $0,3540,784$ & 1,275 \\
\hline
\end{tabular}

Source: Processed primary data, 2019

Table 2 shows the significance value in the Kolmogorov-Smirnov test is 0.109 or $>$ 0.05 which means that the data are normally distributed. The multicollinearity test results in Table 2 show that all independent variables have tolerance value higher than 0.10 and VIF value lower than 10 , which means there are no symptoms of multicollinearity among the independent variables in the regression model. The regression equation model after fulfilling all the classic assumption tests is as follows:

$$
\mathrm{KEP}=11,027+0,572 \mathrm{PGTP}+0,321 \mathrm{SNP}+\mathrm{e}
$$

The results of regression testing on the equation 2 with $\alpha=5 \%$ are used to identify the results of hypothesis testing uji shown in Table 3.

\subsection{Tax knowledge influences the tax compliance}

Good tax knowledge can increase the level of tax compliance. This means that there have been many more UMKM, especially the Course and Training Institution (LPK) that 
TABLE 3: Summary of the Results of Hypothesis Testing

\begin{tabular}{|l|l|c|c|c|}
\hline \multicolumn{1}{|c|}{ Hypothesis } & Coefficient & Significance & Result \\
\hline $\mathrm{H}_{1}$ & $\begin{array}{l}\text { Tax knowledge significantly } \\
\text { influences the tax compliance. }\end{array}$ & 0,572 & 0,000 & Accepted \\
\hline $\mathrm{H}_{2}$ & $\begin{array}{l}\text { Tax sanctions significantly influence } \\
\text { the tax compliance. }\end{array}$ & 0,321 & 0,000 & Accepted \\
\hline
\end{tabular}

Source: Processed primary data, 2019

already have adequate knowledge related tohe $t$ tax regulations to improve their tax compliance. The results of this research are in line with the theory of planned behavior which explains a person's behavior towards his compliance behavior. Someone who has good knowledge about the tax regulations will be much more obedient. However, it is different from someone whose level of taxation knowledge is low that will not comply with the tax regulations. Furthermore, [11] stated that the knowledge, understanding and awareness of the taxpayers will be very important to influence the level of their compliance.

The results of this research are supported by the research conducted by [3] explaining that the taxation knowledge will increase the level of the tax compliance. [14] conducted a study, and the results showed that the tax knowledge has a significant effect on the tax compliance. The research conducted by Putri (2015) showed that the tax knowledge has a positive effect on the taxpayers' compliance.

\subsection{Tax sanctions influence the tax compliance}

Tax sanctions have a strong influence on the level of tax compliance. This shows that with heavy tax sanctions, the taxpayers will be much more compliant when compared to the mild ones. The results of this research are in line with the theory of planned behavior, which explains a person's behavior that arises from his own intention to behave. In this case, if the tax obligation is not implemented properly, then the legal consequences may occur because the taxation contains an element of coercion.

According to [13], the legal consequences referred to are the taxation sanctions. The more severe a sanction imposed by a taxpayer who does not fulfill his taxation obligations, it will effectively affect his compliance. The research conducted by [8] and [9] showed that the tax sanctions have a positive effect on the tax compliance. Furthermore, other research that supports the results is [7], showing a result that the sanctions have a significant positive effect on the tax compliance. 


\section{Conclusions and Suggestions}

Based on the results of the analysis and testing conducted on UMKM taxpayers specifically the Course and Training (LKP) Institution, the tax knowledge and tax sanctions have a positive influence on the tax compliance. This can be interpreted that the taxpayers have sufficient knowledge and are aware of taxation sanctions that will be given if they do not comply with the applicable tax regulations.

Future studies are expected to use other variables that can improve the tax compliance. They are also expected to expand the research scope associated with PP No.23 of 2018 as well as the samples of at least three years or more after the regulation has been effectively applied.

\section{References}

[1] Putri, Christella Pradista Riyana. 2015. Analisis Pengaruh Kesadaran Wajib Pajak, Pengetahuan Perpajakan, Sosialisasi Perpajakan dan Pelayanan Fiskus Terhadap Kepatuhan Wajib Pajak Hotel Melati Di Kota Yogyakarta. Jurnal. Universitas Atma Jaya Yogyakarta 